\title{
The problems of designing a multifunctional courtyard space of high-rise buildings by the example of residential development in Volgograd
}

\author{
Sergei Matovnikov ${ }^{1 *}$, Natalia Matovnikova ${ }^{1}$, Polina Samoylenko ${ }^{1}$ \\ ${ }^{1}$ Volgograd State Technical University, 400047, Volgograd, Akademicheskaya St., 1, Russia
}

\begin{abstract}
The paper considers the issues of designing a modern courtyard space for high-rise buildings in Volgograd to obtain a multifunctional environment through the arrangement of new recreational territories and the search of innovative planning methods for urban landscape design. In professionals' opinion, the problem concerning the design and construction of recreational zones and greenery planting is very acute for Volgograd, such territories are often absent in many districts of the city. Generally, the decrease in the natural component and a low level of recreational territories improvement are typical for Volgograd. In addition, the problem of designing a modern urban courtyard space for high-rise buildings to obtain a multi-functional environment exists and requires a thorough investigation. The question is if there is a possibility to solve these difficult tasks by means of local design methods only or whether there should be a complex approach at the stage of the formation of master plans for modern residential areas and which modern design methods can ensure the creation of a courtyard space as a multi-functional environment. These questions as well as some other ones will be the topic of our paper.
\end{abstract}

\section{Introduction}

The relevance of the chosen topic of designing a modern courtyard space for high-rise buildings as a multifunctional environment is determined by the urgent problem of shortage or deficiency of well-organized courtyard spaces around high-rise buildings in Volgograd. Moreover, the city is particularly concerned about the lack of places for the recreation of citizens in the residential zone $[1,2]$. The needs of city dwellers for recreation are set by the urban planning standards. However, the decrease in the natural component, failure of greenery plantations, a low level of recreational territories improvement are characteristic of the Volgograd Agglomeration [1]. In professionals' opinion, the problem concerning the recreational zones and greenery planting is very acute, they are absent in many districts of Volgograd $[2,3]$. The living conditions get worse due to urban development densification, various types of pollution, ultrahigh concentration of cancer-inducing compounds of sulfur, nitrogen, dust, heavy metals in the air, due to electromagnetic, radioactive, visual and

* Corresponding author: matovnikov4@yandex.ru 
thermal pollution, vibration, noise, spontaneous origination of dumps etc. [4,5]. All these make the issue of increasing the level of urban development comfort in the Volgograd agglomeration the one of the most immediate interest.

Today the recreational territories are more complicated and dynamic in structure, more interactive and mobile from the point of view of the contents. The creation of provocative architectural landscape objects, thematic installations, the application of "performance" design methods in the form of an architectural landscape show are welcome. The new recreation space plays the role of an instrument which inculcates new behavior norms to a consumer, with the help of which new cultural attitudes are announced, old life style stereotypes are ruined $[17,18]$. The modern urban planning principles of urban landscapes design have changed. If earlier recreational territories acted as "concentrated nature" in a city, today the world practice indicates changes in the very philosophy of the creation of urban recreation $[17,18]$. The "clear" boundaries between residential and recreational zones are blurred. The analysis of innovative urban planning methods of design, of modern domestic and foreign projects allowed us concluding that a modern recreational territory "captures" urban space and transforms from a local environment object into an integral urban environment [19]. Designers suggest mobile green lawn parkings for dwellers' recreation, as well as greened walls, roofs, sheds, bridges and modern building envelopes of glass, water and greenery. "Green mazes" made of trees, shrubs, sculptures as well as installations, unusual water reservoirs, fountains, green sculptures of ornamental shrubs and trees are arranged in recreational territories. When an urban landscape is designed, the whole complex of components is taken into account: real and virtual space, its external and internal life processes, the items used, the whole socially oriented infrastructure of a recreational territory. The ways are determined how to create an interactive environment, a visitor is involved into a gaming communication, cooperation, training. It is necessary to note that the arrangement of urban recreational territories as multifunctional urban complexes increases their "recreational capacity". However, it should be recognized that construction in the recreational territories of residential districts increases the load on the territory and requires additional efforts aimed at the natural landscape preservation $[19,20]$.

In the new Master plan of Volgograd, the "green frame" concept of the Volgograd agglomeration has been developed, since the system of green wedges which plays the role of protective zones preventing the negative influence of urbanization drawbacks on the urban landscapes is the optimal structure of massive green plantations for most large cities $[21,22,23,24]$. Public green plantations are designed at the area of 2570 ha, which ensures the urban greening level of 23 sq.m. per citizen. The increased norm of greening in the complicated climatic conditions of Volgograd will contribute to the creation of favourable sanitary-and-hygienic situation, to the improvement of the urban microclimate. However, the territory of the Volgograd agglomeration is ill-adjusted to the fulfillment of the stated task, which is determined by a number of reasons. According to the climatic conditions, it is situated in the dry steppe zone and is characterized by extremely arid climate with explicit continentality. The mean annual duration of sunshine is 2221 hours. [7]. The mean value of total solar radiation equals to $113,4 \mathrm{kcal} / \mathrm{cm}^{2}$ per year. The annual radiation balance is positive and averagely makes up to $50,1 \mathrm{kcal} / \mathrm{cm}^{2}$. The openness of the territory contributes to the barrier-free penetration of cold air masses both from the north and the east in winter. In summer dry air comes from the Middle East and Central Asia when very hot and dry weather is set: the air temperature reaches $34-38^{\circ}$, the relative humidity decreases to $10-12 \%$. Increased wind velocities are conductive to the origination of dust storms which happen 5-14 days per year [8]. According to the hydrometeostation data of Volgograd State Agrarian University, the absolute minimum for the Volgograd region is $41^{\circ}$, while the maximum is $+45^{\circ}$. 
The soils in Volgograd and its surroundings formed mainly on loess loams and clays, and on loamy sands and sands at some plots. The soils show low-level fertility, the humus content is usually not high (up to $2 \%$ ). Concerning the fitness for forests, meadow-chestnut soils are the best ones in the chestnut zone. They stand out for darker color, higher humus content, larger number of nutrition elements and have a better structure. In the right-bank part of the Volgograd territory, the main relief forms determining the soils formation are gullies, cloughs, ravines, while in the left-bank part, in the territory of the Volga-Akhtuba flood plain, they are saucer-shaped depressions. The average depth of humus horizon is 40$45 \mathrm{~cm}$, reaching $70-75 \mathrm{~cm}$ at particular plots. The humus amount in upper horizons varies from $2,5 \%$ to $4,5 \%$. These soils can be used for recreational and protective forestation when appropriate irrigation regime is followed. A significant part of the Volgograd agglomeration soils are polluted to a high degree $[9,10]$. The local vegetation is rather poor as according to the forest zoning the Volgograd agglomeration belongs to the territory of the Northern semi-desert of Yergeny and Eastern Ciscaucasia in the province of the southern part of the Russian plain of the Eurasian steppe zone [11]. The natural tree vegetation of the zone is represented by ravine forests of pedunculate oaks (Quercus robur) with aspens (Populus tremula), smooth-leaved elms (Ulmus carpinifolia), common elms (Ulmus laevis) and wild apple-trees (Malus sylvestris). Typical steppe shrubs: crenulated spirea (Spiraea spiraca) and hypericifolia one (Spiraea hypericifolia), ground cherry (Cerasus fruticosa), dwarf almond (Amyqolalus nana) form tangled vegetation at forest verges. Oak ravine forests grow in cloughs with a lower location and the most favourable soil and hydrological conditions [12]. It is necessary to note that the forests of the VolgaAkhtuba flood plain situated on the Volga bank opposite to Volgograd are of extraordinary value. They are of great recreational, climate-regulating, sanitary-and-hygiene, waterprotective and erosion-resisting significance. Here, oak forests are the most valuable - pure or with an admixture of common elms [4,12]. However, this territory of the Volgograd agglomeration is the National Park and therefore belongs to the recreational territories of restricted usage. The artificially planted urban greenery in Volgograd is represented to a great degree by the plantations of alien forms of Bolle's poplar and Black poplar, which are characterized by a relatively short life time [13]. In addition, the geomorphologic structure, the surface waters and hydrogeology of the Volgograd territory also cause problems when urban parks are designed. According to the geomorphologic zoning it belongs to the accumulation-denudation southern part of the Volga Upland [14]. The characteristic feature of the northern part of the city is a high ledge of the Yergeny surface comprised of a layer of white inequigranular sands up to $8 \mathrm{~m}$ deep. To the south of it at the Volga bank, there is an abrasion-and-accumulation marine terrace $(20-40 \mathrm{~m}$.) and two terraces above the flood plain with mean relative heights of $10-15 \mathrm{~m}$ and $50-60 \mathrm{~m}$. In the urban territory, in the interstreams of the Sukhaya Mechetka and Mokraya Mechetka rivers as well as in the mouth of the Tsaritsa river, low-rise terrace-like steps are composed of chocolate clays. In the rest of the territories, the chocolate clays surface merges invisibly with the more abrasive surface of the terrace of $20-40 \mathrm{~m}[8,15]$. The surface waters are represented by the rivers of Volga and Akhtuba as well as by small rivers (Tsaritsa, Mokraya Mechetka, Sukhaya Mechetka), the Volgo-Don Shipping Canal, a series of Sarpinskie lakes, and numerous lakes of the Volga-Akhtuba flood plain [16]. The depth of location and the chemical properties of the subterranean waters depend on the degree of the relief roughness, at the watershed and near-watershed areas the subterranean waters are located at the depth lower than 10 metres. At the bottoms of cloughs, gullies and ravines, in the river flood plains and the lower terraces of lakes they can occur at the depth (up to 1-2 metres) available for roots or even come to the surface during spring time. In the north of the Yergeny Upland, subterranean waters are located in sands and loams of the Yergeny suite at the depth of 30 - 40 metres which can be reduced to 1 meter in gullies. In the 
surroundings of Volgograd and Volzhsky, near detention-evaporation basins, the subterranean waters are highly polluted. The area of the polluted subterranean waters spreading is more than $970 \mathrm{sq}$. $\mathrm{km}$. All these stipulate definite difficulties for the creation of comfortable urban landscapes and make us search for alternative ways of urban recreational territories arrangement, use innovative urban planning methods of urban landscape design $[20]$.

\section{Methods}

In this regard, a range of scientific and applied issues concerning the design of courtyard space for high-rise buildings aimed at obtaining a multifunctional environment was identified. The study of the relevant normative documents, the analysis of the modern urban planning situation in Volgograd and experts' advice allowed us determining the content of the first stage of the research: to carry out a preliminary analysis of the existing courtyard spaces of high-rise buildings in Volgograd in terms of their functioning as a multifunctional environment. We conducted observations of certain situations typical for Volgograd in the existing courtyard spaces of various types of high-rise buildings. In addition to the examination and observation, the initial stage of the research included the aerospace photography and field photo survey of the courtyard spaces. The residents of the given buildings were also offered a questionnaire. The data collected helped us conduct an objective and adequate assessment of the existing territory improvement and of the functioning of modern courtyard spaces serving high-rise residential buildings and draw some preliminary conclusions that will be covered in this article.

According to the type, courtyard spaces in modern construction are divided into monofunctional and polyfunctional (multifunctional) ones. The first subgroup includes, for instance, the courtyards where only a children's playground is located, i.e. the territories that perform a strictly defined function and are designed for a narrow audience. Such spaces, in our opinion, are intended only for a certain group of the inhabitants of a particular residential development. The creation of a monofunctional space is, indeed, a justified, logical step dictated by objective reasons of the lack of space that could be used for a courtyard. Oftentimes, however, it becomes an example of explicit discrimination of groups of people who live in these buildings (actually, children's interests are often neglected). The second subgroup of polyfunctional courtyard spaces refers to the spaces that include various functional zones, it means the territory is designed and zoned in accordance with the interests of the major part of the residents. In our opinion, nowadays, it is the multifunctional courtyard space that most accurately meets various needs of a modern city resident. Only the construction and arrangement of a multifunctional courtyard territory can create a unique, exceptional and comfortable urban courtyard environment as a part of sound urban recreation.

The urban environment of a modern courtyard should be built on the principles of accessibility, equality of interests of all population groups, their social, ecological and ethical safety. Residents of a city should feel that "their" territory is not only the one that is located next to their house but the whole city as well. Furthermore, the main visitors and users of courtyard spaces are children, parents, their supervisors, and elderly people, that is, groups of residents who cannot stay at a large distance from their homes for a long time. Besides, the process of disunity for the majority of urban residents, which is currently taking on alarming proportions, is largely rooted in the unsettledness and inconvenience of courtyard areas, and, oftentimes, in their complete absence. Today urban courtyards are often deserted or are instead filled with personal vehicles of the residents. Therefore, we believe that it is solely the design of a courtyard as a multifunctional environment that allows not only taking into account the interests of the most, if not all of the resident 
groups, but also returning the interest of the residents to their courtyards, and inspiring a new life in those spaces.

For this study, we selected courtyards typical of the Soviet period of territory development, and several modern variants of courtyards of high-rise buildings. Historical background: the construction of high-rise buildings (12, 14, 16 floors) in Volgograd began in the late 60 s of the XXth century. At that time, many courtyards for Volgograd were designed by the Leningrad Institute of General Planning. The attachment to the terrain was carried out by the workshop No. 1 of Volgograd Grazhdan Proekt Institute (the head of the workshop V.P. Statun). According to A. M. Vyazmin, the former chief architect of Volgograd, the old courtyards were designed in compliance with the SNiP (Construction Rules and Regulations); that is, the organization carried out territory zoning, designed a path-and-road network, provided options for improvement, etc. The committee did not allow for a constructed building acceptance without these requirements being fulfilled. The approval of the courtyard draft at the Sanitary and Epidemiological Station was an obligatory condition. Some buildings in the Central district of Volgograd were even designed with underground parking spaces (for up to 54 cars per building). Typical equipment for children's playgrounds (slides, swings, carousels, benches, etc.) was also designed, and was consequently installed in each courtyard. However, the construction of courtyard territories was not always completed. There were "inconsistencies" in the plans concerning the schedule of commissioning, or financing. Design and construction of courtyards were often funded by a residual principle. Nowadays, in the opinion of the expert community, courtyards of high-rise buildings are not designed; they "remain at the mercy of the developer" and the expert commission does not pay any attention to the condition of the courtyard territory.

\section{Results}

Two "historical" examples of the organization of courtyard space located near sixteenstorey buildings in the Central District of Volgograd were considered: 1) Courtyard No.1 in Dnestrovskaya Street (Fig. 1,a) - a courtyard of a section-type multi-storey panel building (the general layout of the courtyard executed by Volgograd Grazhdan Proekt Institute); 2) Courtyard No.2 in Parkhomenko Street (Fig. 1,b) -a courtyard of a section-type multi-storey brick building (the general layout of the yard executed by Leningrad Institute of General Planning).

Courtyard No. 1: a lived-in one, but the existing situation and improvement efforts make a rather modest impression (if not less). The courtyard area is quite large (more than 0.5 hectares), it is open in the direction of the roadway (intra-quarter passage). There is no either sufficient isolation from the noisy transit zone, or clear and definite zoning of the courtyard space, the vertical layout of the territory is missing or minimized, the equipment is obsolete, the options for improvement are minimized, etc. According to the survey of residents, the courtyard territory does not meet modern requirements, it looks deserted and abandoned. Another drawback of this yard is its extremely low isolation and minimal privacy. For family recreation, citizens prefer to go out into the city, where places for recreation by interests are available (e.g. cinemas, cafes, sports grounds, etc.).

Courtyard No. 2: smaller in size (about 0.25 hectares), open from both sides, both towards the city roadway and the passage. However, the design tasks are solved more successfully here. The courtyard is perceived as private and is isolated from the noisy transit zone due to the construction of a decorative 1.5-meter high wall delimiting the courtyard. This method made it possible to clearly divide the area into two partially isolated territories (a children's zone and the recreation zone for the other residents of the building). Besides, "pockets" for car parking and some household needs of residents, such as garbage 
collection, carpet cleaning, etc., are organized in the local area. There are various forms of landscaping present in the courtyard. Thus, such a drawback of the territory as its small area did not prevent from designing a cozy and quite a private courtyard. The shortage of parking places for tenants' vehicles, the outdated equipment of the children's playground and utility zones can be considered disadvantages of this yard (during the Soviet time an underground parking was planned to be built in this yard).
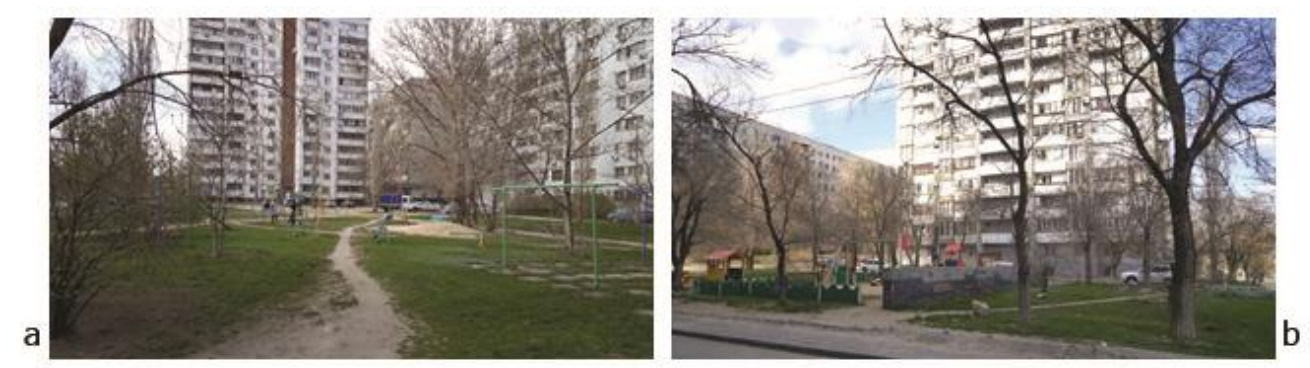

Fig. 1. "Historical" examples of the organization of courtyard space: a - courtyard No.1 in Dnestrovskaya Street,

b - courtyard No. 2 in Parkhomenko Street

In current development, the following urban planning situations in the Central district of Volgograd were taken to investigate courtyard spaces of high-rise houses: 1 . Kalinin street courtyard of a two-section high-rise building (an individual design project of "Volzhskie Parusa" (Fig.2, a); 2. Pugachevskaya Street - courtyard of a corridor-type multi-storey panel building (Fig.2, b); 3. Nevskaya Street - courtyard of a two-section high-rise building (Fig.2,c); 4. Donetskaya Street - courtyard of a multi-sectional high-rise residential buiding (Fig.2, d);

\section{Discussion}

The feasibility study of the chosen topic was shifted from the plane of scientific debate to the plane of the study of the actual needs of residents of high-rise buildings. The survey conducted among the inhabitants of these buildings showed that there are various age groups, various social and national groups of residents living in the aforementioned residential buildings, in the other words, a regular segment of population of a modern city. Here are the basic wishes of the residents that they would like to see realized in the territory of their courtyard spaces. In a modern courtyard, according to the tenants who took part in the survey, there should be: 1 . Sidewalks for mothers walking with children in baby carriages; 2. Children's playgrounds for children with parents accompanying them; 3 . Bike paths and tracks for skateboards; 4. Playgrounds for team games; 5. Sportsgrounds with sports equipment; 6 . Isolated zones for quiet secluded rest; 7. Pavilions for communication by interests; 8 . A place for general meetings; 9. Territory for dog walking; 10. Parking spaces located away from children's playgrounds. This list of wishes could be expanded. In our opinion, it is convenient to have a summer stage or an open-air cinema in the courtyard area, places for private entrepreneurship or home-based work (e.g. mini bakery, tailor's shop, hairdresser's, shoe repair shop, etc.), green park islands and small decorative ponds, etc. $[11,19]$. 

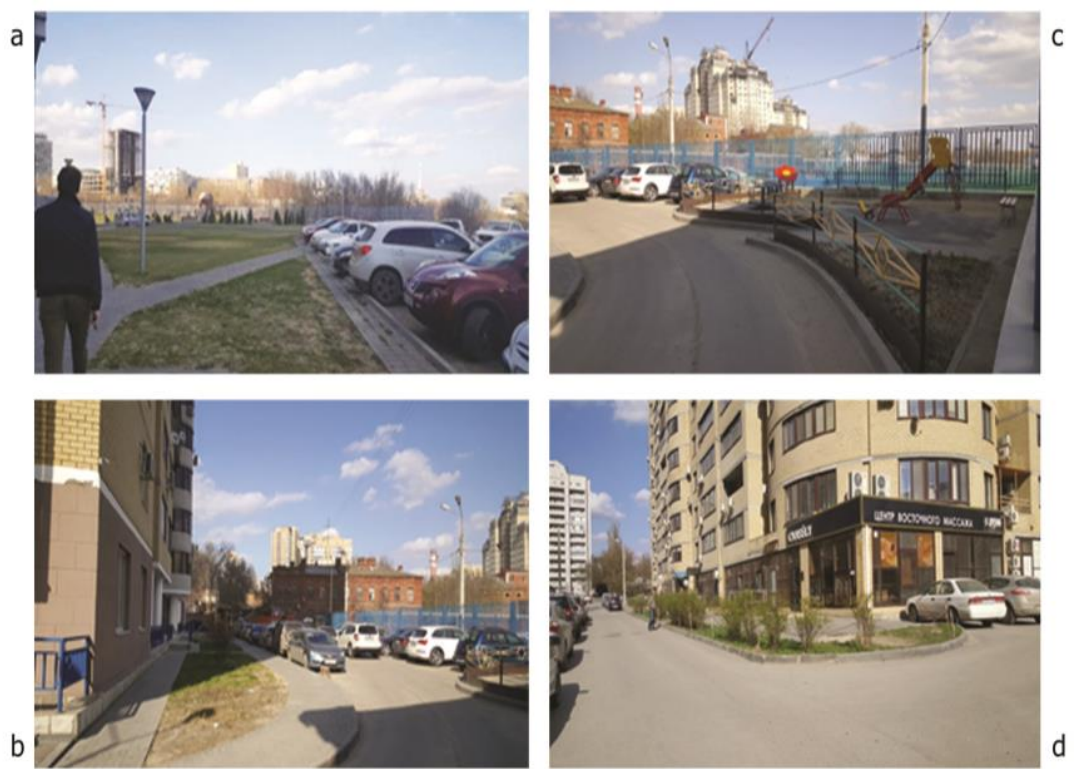

Fig.2. Examples of the existing courtyard spaces of high-rise buildings, typical for Volgograd: a Kalinin street - courtyard of a two-section high-rise building (an individual design project of "Volzhskie Parusa"; b - Pugachevskaya Street - courtyard of a corridor-type multi-storey panel building; c - Nevskaya Street - courtyard of a two-section high-rise building; d - Donetskaya Street courtyard of a multi-sectional high-rise residential buiding.

\section{Conclusions}

The carried out initial observation of the considered courtyard territories allowed for a preliminary conclusion that, at the present time, no modern courtyard space under investigation has a design which meets the needs of all the groups of tenant living in the buildings nearby. Thus, we can see that the problem of designing a modern urban courtyard space for a high-rise building as a multifunctional environment exists and requires a thorough investigation. The question is if there is a possibility to solve these difficult tasks by means of local design methods only or whether there should be a complex approach at the stage of the formation of master plans for modern residential areas. Which modern design methods can ensure the creation of a courtyard space as a multifunctional environment. These and other questions will be a topic for our further research.

\section{References}

1. L. Kremer, G. Vinter, Environmental Law of the European Union, 144 (Moscow, Gorodets, 2007)

2. G. N. Kovalyova, State of recreational spaces in Volgograd we present stage and their impact on the socio-cultural life of the city 3(13) (Polythematic, 2010) URL: http; // www.vestnik.vgasu.ru/

3. E. V. Shagieva, E. A. Baranska, O. G. Chesnokova, Environmental problems of the city of Volgograd, Construction and architecture, 39(58), 110-117 (2015)

4. The report "On the state of the environment of the Volgograd region in 2011" 325 (Volgograd "SEE", 2012) 
5. The report "On the state of the environment of the Volgograd region in 2010" 352 (Moscow "Globus", 2011)

6. V. N. Anopin, Geographical bases of forest reclamation of degraded urbolandscapes Lower Volga region, 169, (Volga-grad, 2005)

7. A. N. Sazhin, Modern climate change and zonal agri - ecology problems (for example, the Lower Volga region), Problems of regional ecology, 1, 14-20 2001

8. The report "On the state of the environment of the Volgograd region in 2009", 304 (Moscow "Globus", 2010)

9. V. A. Brylyov, The natural conditions of the Volgograd region (Ed. Brylëv V.A.) 122, 264 (Volgograd, "Change", 1996)

10. State report "On the state and Environmental Protection of the Volgograd region in 2002", 300, (Moscow, NIA Nature REFIA, 2003)

11. N. D. Sashnin, Research of ways of the basic processing of light-chestnut soils in combination with saline soils for growing protective forests on the right bank of the Volgograd Volga Abstract of thesis ... cc-Agricultural Sciences, 25 (Volgograd, 1981)

12. S. Shmelyov, I. Shmelyova, Stable city: problems of interdisciplinary research. Int. Journal of Stable Development, 12, 23 (2009)

13. E. E. Krasilnikov, Landscape Urbanism, Theory and practice. Part 1: the scientific and practical bases of landscape Urbanism: monograph, 156 (Volgograd: Lld "IAA" Regional news ", 2015)

14. E. S. Migunova, Plantations on saline soils, 99, 140 (Moscow, Forestry, 1978)

15. V. N. Anopin, N. G. Matovnikova, Condition and methods to improve the attractiveness urbolandscapes South Russian Gazette geology, geography and global ecology 15(18), 99-102 (Astrakhan, 2006)

16. N. G. Matovnikova, Biogeographical bases landscaping of recreational areas of the Volgograd agglomeration, Abstract PhD of Sciences in geography, 25 (Volgograd, 2007)

17. V. N. Anopin, S. A. Matovnikov, N. G. Matovnikova The Features of the Establishment and Maintenance of Parkland in the Solution of the Problems of Urban Agglomerations in Volgograd, Procedia Engineering, 150, 1972-1977 (2016)

18. S. A. Matovnikov, N. G.Matovnikova. Innovative Urban Planning Methods for the Urban Landscape Design in the Volgograd Agglomeration, Procedia Engineering, "2nd International Conference on Industrial Engineering” ICIE2016, 2, 1966-1971

19. E. E. Krasilnikov, Landscape Urbanism. Theory and practice.Part 1: the scientific and practical bases of landscape Urbanism: monograph, 156 (Volgograd: OOO "IAA" Regional news ", 2015)

20. S. A. Matovnikov, N. G. Matovnikova, Some current trends in the theory and practice of designing urban parks Science and education: architecture, urban planning, construction of: Proceedings of the International meeting., 6-10 September 2010, Volgograd, 386-391 (Volgograd: VolgGASU, 2010)

21. S. A. Matovnikov, N. G. Matovnikova, Creating a comfortable multisensory environment as the actual problem of the modern park construction, 22(41), 155-164 (2011)

22. V. N. Anopin, N. G. Matovnikova, S. A. Matovnikov, Architectural planirovochnve and adaptive landscape basics of green building in the Volgograd agglomeration, 159 (VolgGASU, Volgograd, 2012) 
23. The decision of the Volgograd City Duma from 29.06.2007 № 47/1112 «On the approval of the Master plan of Volgograd".

24. A. V. Antyufeev, "Large Volgograd" in the program of development of Russian megalopolises century, the annual scientific materials, Architecture, urban planning and construction, 9-11 (Volgograd: VolgGASU, 2008)

25. L. I. Abakumov, Influence of industrial emissions on the stability of trees and shrubs, In sb. gardening problems, Gradostroitelnye, environmental, sanitary and hygienic aspects, 36-37 (Volgograd, 1995)

26. V. A. Gorohov, The green nature of the city: a textbook for high schools. Ed. 2nd, 528 (Moscow,.Architecture, 2005) 